\title{
Film forming properties of Cissus pulpunea (Guill and Perr) and Irvingia gabonensis ( $0^{\prime}$ Rorke) gums
}

\author{
Tolulope Omolola Ajala ${ }^{1, B-F}$, Hope Idemudia Olaiya ${ }^{2, B, C, F}$, Oluwatoyin Adepeju Odeku ${ }^{2, A, C, E, F}$ \\ 1 Department of Pharmaceutics and Industrial University of Ibadan, Ibadan, Nigeria \\ 2 Department of Pharmaceutics and Industrial Pharmacy, Faculty of Pharmacy, University of Ibadan, Ibadan, Nigeria \\ A - research concept and design; $B$ - collection and/or assembly of data; $C$ - data analysis and interpretation; \\ $D$ - writing the article; $E$ - critical revision of the article; $F$ - final approval of article
}

\section{Address for correspondence \\ Tolulope Omolola Ajala}

E-mail: tolulola1721@gmail.com

\section{Funding sources}

none declared

\section{Conflict of interest}

none declared

\section{Acknowledgements}

The authors acknowledge Mr Bukola Omoniyi for his assistance during the experiments.

Received on January 6, 2017

Revised on March 19, 2017

Accepted on July 24, 2017

\begin{abstract}
Background. Natural polymers such as gums have gained attention in drug delivery systems due to their availability, compatibility and degradation under natural and physiological conditions.

Objectives. The aim of the present study was to investigate the film forming properties of gums obtained from the stem of Cissus polpunea (Guill and Perr) and the seed of Irvingia gabonensis (0'Rorke).

Material and methods. Gums were extracted from the relevant plant parts and characterized using functional, proximate and elemental properties. Films were prepared by the casting method using gum concentrations of $1-4 \% \mathrm{w} / \mathrm{v}$ and varied with propylene glycol (PG). The films were assessed through physical observation, thickness, swelling power and moisture sorption effects using the relative humidity of $0,27,43,57,75$ and $90 \%$. The gum yielding optimal film properties was used as coating material in ibuprofen tablet formulations. The mechanical and release properties of the tablets were determined.

Results. The functional and proximate properties of gums showed a similarity in the majority of the parameters, but significant $(p<0.05)$ variation existed in their solubility, while elemental assessment revealed the absence of toxic metals. Generally, the films were homogenous, opaque and demonstrated high swelling power in phosphate buffer, which was pH-dependent. Moisture sorption properties of the gums increased with the increase in relative humidity in the order $H P M C<$ Cissus $<$ Irvingia. Film-coated ibuprofen tablets showed higher mechanical properties and disintegration and dissolution times compared with uncoated tablets.
\end{abstract}

Conclusions. Cissus and irvingia gums have demonstrated acceptable functional, proximate and elemental properties. Film-coated ibuprofen tablets showed higher mechanical and release properties than was the case in uncoated tablets.

Key words: Cissus polpunea gum, Irvingia gabonensis gum, ibuprofen tablet, film and coating properties

DOI

10.17219/pim/76059

Copyright

○ 2017 by Wroclaw Medical University

This is an article distributed under the terms of the Creative Commons Attribution Non-Commercial License (http://creativecommons.org/licenses/by-nc-nd/4.0/) 
Polymers are widely used in drug delivery systems as film-forming materials for coating tablets either to protect the core of the tablet against degradation, mask taste or for sustained and controlled release dosage forms. ${ }^{1}$ Natural polymers have gained attention as a drug delivery system due to their availability, compatibility and degradation under natural and physiological conditions. ${ }^{2}$

Cissus gum is obtained from the stem and roots of Cissus pulpunea (Guill and Perr), family Ampelidacea. Cissus is a genus of approximately 350 species of woody vines in the grape family Amplidaceae (Vitaceae). Cissus gum is traditionally used in the preparation of soup amongst the Idomas of Benue State and the Igalas of Kogi State of Nigeria. ${ }^{3}$ It has also been used as a foam stabilizer in preparing 'akara' balls. ${ }^{4}$ On the other hand, Irvingia gum is obtained from Irvingia gabonensis (O’Rorke) Bail (family Irvingiaceae), commonly known as African mango or 'bush mango', which is a tree of 15-40 m with a slightly buttressed hole. ${ }^{5}$ The kernels from the tree are called oilseeds and have various local names: in Nigeria, such as 'ogbono' in Ibo and 'apon' in Yoruba. ${ }^{6}$ The kernels are ground with a pestle and mortar or on a stone into a paste or cake called 'dika bread', which is used as a soup, stew or sauce additive, for flavoring and thickening. ${ }^{7}$ The kernels are also highly valued for the slimy consistency they produce because of the presence of mucilage. The mucilage has been reported to be a binding agent in tablet formulation, especially when slower disintegration and dissolution rates are desired ${ }^{8}$ and the emulsifying and suspending properties have also been studied. ${ }^{9}$

In a recent study, some material properties of both gums (Cissus and Irvingia) such as porosity, phase transition, $\mathrm{X}$-ray diffraction patterns, gelatinization temperature, heat of gelatinization, mean particle size and specific surface area were assessed and the results showed acceptable excipient potentials; furthermore, the gums successfully served as polymers in microbead design. ${ }^{10}$ In addition, unpublished data also showed that Cissus and Irvingia gums lacked toxicity against different cell lines. However, the prospect of these gums in film formation and coating of tablets for immediate release has not been evaluated. Consequently, the film-forming properties of the gums in comparison with hydroxypropyl methyl cellulose (HPMC - a standard polymer used in the food and pharmaceutical industry) have been evaluated and optimal concentration of the films was used for coating ibuprofen tablet formulation.

\section{Material and methods}

\section{Material}

The materials used included: ibuprofen powder obtained from Vital Medix Nigeria Limited (Ibadan, Nigeria), HPMC E5 Premium LV was obtained from Colorcon limited (Flagship House, Kent, England), propylene glycol (PG) was procured from BDH Chemicals Limited (Poole, England). Kernels of Irvingia gabonensis were purchased from Ojoo market in Ibadan (South Western Nigeria) while the stems of Cissus pulpunea were purchased from Bode market also in Ibadan (South Western Nigeria).

\section{Harvesting and extraction of Irvingia gabonensis gum}

Irvingia gabonensis kernels were harvested from the fruit by dehulling, and extraction was done using an established method. ${ }^{8}$ Then, dried kernels of Irvingia gabonensis (without the seed coats) were powdered using a laboratory mill and then macerated in petroleum ether for $24 \mathrm{~h}$, and then strained through a calico cloth to obtain particulate-free slurry. The extract separated from the residue was repeatedly soaked in petroleum ether until there was no more fat obtained in the petroleum ether. The fat-free residue was hydrated in chloroform water (double strength) for 5 days and Irvingia gum was precipitated with ethanol. The precipitated gum was washed with diethyl ether and dried in a hot air oven (Model 77-9083, Techmel\&Techmel, China) at $50^{\circ} \mathrm{C}$ for $48 \mathrm{~h}$. The dried gum was pulverized using a porcelain mortar and pestle. The fine particles were screened through a stainless steel sieve $(250 \mu \mathrm{m})$ and stored in an airtight container in a dessicator prior to use.

\section{Harvesting and extraction of Cissus pulpunea gum}

The stems of Cissus pulpunea were cut by local farmers, cleaned, assembled and sold in a local market. Cissus stems were procured and prepared for extraction by scraping the stems with a knife to remove the outer layer of the stem. The scraped stems were washed in clean water and chopped into tiny bits ready for gum extraction. The chopped strips were soaked in chloroformwater double strength for $48 \mathrm{~h}$. The gums were strained through calico cloth to remove extraneous materials and then precipitated with absolute alcohol. The precipitated gum was filtered and washed with diethyl ether. The purified gums were dried in a hot air oven (Model 77-9083, Techmel\&Techmel, China) at $40^{\circ} \mathrm{C}$ for $48 \mathrm{~h}$ and then pulverized and kept in airtight containers. ${ }^{11}$

\section{Proximate analysis}

The proximate constituents were determined using established procedures. ${ }^{12}$ Standard AOAC methods were used to determine ash content (method 942.05), crude fiber (method 958.06), and moisture by the hot air oven method (method 925.09), crude protein was determined by routine semi-micro Kjeldahl method (Method 988.05) and (2003.06) in both Irvingia and Cissus gum powder. 


\section{Elemental constituents}

The powdered gum $(0.5 \mathrm{~g})$ was weighed and placed in a $125 \mathrm{~mL}$ Erlenmeyer flask, which has been previously washed. Perchloric acid $(4 \mathrm{~mL})$, concentrated nitric acid $(25 \mathrm{~mL})$, and $2 \mathrm{~mL}$ concentrated sulphuric acid were added into the content in the flask. The contents were mixed gently at a low temperature on a hot plate in a perchloric acid fume cupboard. The heating was continued until dense white fumes appeared. Finally, the mixture was heated strongly (medium to high heat) for half a minute. This was allowed to cool, and then distilled water 40-50 mL was added and boiled for half a minute on the same plate at medium heat. Distilled water was added till the volume reached the $100 \mathrm{~mL}$ mark. The elemental constituents were then evaluated using Atomic Absorption Spectrophotometer (AAS, model 2500 Torontech, Inc., Toronto, ON, Canada).

\section{Solubility}

The solubility of the gums was done in water in accordance with the modified method described by Kaur et al. ${ }^{13}$ The gum $(1.0 \mathrm{~g})(\mathrm{w})$ was weighed into a $100 \mathrm{~mL}$ conical flask, $15 \mathrm{~mL}$ of distilled water was added and shaken slowly for $5 \mathrm{~min}$, then transferred into a water bath and heated for $20 \mathrm{~min}$ at $80^{\circ} \mathrm{C}$ with constant stirring for $1 \mathrm{~h}$. The mixture was then transferred into a pre-weighed centrifuge tube $\left(\mathrm{w}_{1}\right)$, distilled water $(7.5 \mathrm{~mL})$ was added and centrifuged (TDL-5, Mumbai, India) at $2200 \mathrm{rpm}$ for $20 \mathrm{~min}$. The supernatant was then carefully decanted into a pre-weighed dish $\left(\mathrm{w}_{2}\right)$, dried at $100^{\circ} \mathrm{C}$ to a constant weight $\left(\mathrm{w}_{3}\right)$ and cooled for $30 \mathrm{~min}$. From the weight taken, the solubility in percentage was calculated using equation 1 :

$$
\text { solubility }(\%)=\left(\mathrm{w}_{2}-\mathrm{w}_{3} / \mathrm{w}\right) \times 100
$$

\section{Water absorption capacity}

Water absorption capacity (WAC) was determined by placing the gum $(2.5 \mathrm{~g})$ in a weighed $50 \mathrm{~mL}$ centrifuge tube and $15 \mathrm{~mL}$ distilled water was added. Agitation on a vortex mixer was done for $2 \mathrm{~min}$ and later centrifuged (TDL-5, Mumbai, India) at $400 \mathrm{rpm}$ for $20 \mathrm{~min}$ and the supernatant was decanted. The supernatant was discarded, the residue was weighed $\left(\mathrm{w}_{1}\right)$ and the absorbed drops of water were removed by drying at $100^{\circ} \mathrm{C}$ to a constant weight $\mathrm{w}_{2}$ in an oven. Water absorption capacity was expressed as the weight of water bound by $100 \mathrm{~g}$ of sample and calculated using equation 2 :

$$
\mathrm{WAC}=\left\{\left(\mathrm{w}_{1}-\mathrm{W}_{2}\right) / 2.5\right\} \times 100
$$

\section{Swelling index}

The gum $(5 \mathrm{~g})$ was placed in each of $100 \mathrm{~mL}$ measuring cylinder and the volume occupied was noted $\left(\mathrm{v}_{1}\right)$. Distilled water $(90 \mathrm{~mL})$ was gradually added with agitation for $5 \mathrm{~min}$ and then made up to volume $(100 \mathrm{~mL})$. The mixture was allowed to stand for $24 \mathrm{~h}$ and the volume occupied after settling $\left(\mathrm{v}_{2}\right)$ was measured. The swelling index was computed as follows:

$$
\text { swelling index }=\mathrm{v}_{2} / \mathrm{v}_{1}
$$

\section{Viscosity}

The viscosities of aqueous dispersions (1, 2, 3 and $4 \% \mathrm{w} / \mathrm{v}$ ) of each polymer (Irvingia, Cissus and HPMC) were determined using a Brookfield viscometer (RVDV-II+P, Middleboro, U.S.A) with spindle 4 and shear rate of $100 \mathrm{rpm}$ at $25 \pm 2^{\circ} \mathrm{C}$.

\section{Preparation of films}

A homogenous and clear dispersion (2, 3 and $4 \% \mathrm{w} / \mathrm{v})$ of the gum was prepared by dispersing the weighed amount of the gum in distilled water and gradually heating with stirring $(100 \mathrm{rpm})$ for $30 \mathrm{~min}$ at $70 \pm 5^{\circ} \mathrm{C}$. The solution was then filtered through a calico cloth to remove undissolved particles and $20 \mathrm{~mL}$ was transferred to a petri dishes having $9 \mathrm{~cm}$ internal diameter. The petri dishes were placed on leveled surfaces for casting and then the films were dried in a hot air oven (Model 77-9083, Techmel\&Techmel, China) at $50^{\circ} \mathrm{C}$ for $48 \mathrm{~h}$. The films were carefully removed from the Petri dish and equilibrated at $25 \pm 2{ }^{\circ} \mathrm{C}, 58 \%$ relative humidity for $24 \mathrm{~h}$ in a glass dessicator.

\section{Determination of film thickness}

The thickness of the films was measured with a micrometer screw gauge (sensitivity of $0.001 \mathrm{~mm}$ ). Then measurements were taken at random locations on the film and the mean values were calculated.

\section{Moisture sorption of gum and prepared films}

Moisture sorption isotherm was determined by cutting the films into $25 \times 10 \mathrm{~mm}$. The dried films or powdered gums were placed inside a vacuum dessicator maintained at $0,27,43,57,75$, and $90 \%$ relative humidity $(\mathrm{RH})$ using super saturated solutions of different solutes kept at $25 \pm 2^{\circ} \mathrm{C}$ and equilibrated for 14 days. The amount of water absorbed was determined by re-weighing the containers and the contents. The moisture sorption curve was obtained by plotting a graph of percentage moisture content vs percentage relative humidity. ${ }^{14}$ 
Percentage moisture sorption was calculated from the formula below:

$\%$ moisture content $=\left\{\left(\mathrm{M}_{\mathrm{ae}}-\mathrm{M}_{\mathrm{be})} / \mathrm{M}_{\mathrm{be}}\right\} \times 100\right.$

where: $M_{\mathrm{ae}}=$ mass after equilibrium,

$\mathrm{M}_{\mathrm{be}}=$ mass before equilibrium .

\section{Swelling index of dried film}

The swelling index was determined by placing an accurately weighed (w) film with area of $1 \mathrm{~cm}^{2}(1 \times 1 \mathrm{~cm})$ in a flask containing $250 \mathrm{~mL}$ of phosphate buffer $\mathrm{pH} 4.75$, 6.0 and 7.4 at $37 \pm 2{ }^{\circ} \mathrm{C}$. Swollen samples were withdrawn from the medium and weighed $\left(\mathrm{w}_{\mathrm{s}}\right)$ after the removal of excess surface water by light blotting with Whatman paper. The swelling index (\%) was calculated as using equation 7 below:

$$
\text { swelling index }(\%)=\left\{\left(\mathrm{w}_{\mathrm{s}}-\mathrm{w}\right) / \mathrm{w}\right\} \times 100
$$

\section{Preparation of granules}

Batches (300 g) of a basic formulation of ibuprofen (73\% w/w), corn starch $(9 \% \mathrm{w} / \mathrm{w})$, PVP $(2 \% \mathrm{w} / \mathrm{w})$, sodium benzoate $(1 \% \mathrm{w} / \mathrm{w})$, magnesium stearate $(2 \% \mathrm{w} / \mathrm{w})$ and lactose $(14 \% \mathrm{w} / \mathrm{w})$ were dry-mixed for $5 \mathrm{~min}$ in a Kenwood planetary mixer (Model A120, Hobart Manufacturing Co, U.K). The PVP was prepared as mucilage and used to moisten the dry-mixed powder to produce granules. Massing was continued for $5 \mathrm{~min}$ and the wet masses were granulated by passing them manually through a number 12 mesh size $(1400 \mu \mathrm{m})$, dried in a hot oven for $4 \mathrm{~h}$ at $50^{\circ} \mathrm{C}$ and then re-sieved through a number 16 mesh sieve $(1000 \mu \mathrm{m})$. The granules were then stored in airtight containers.

\section{Preparation of tablets}

Tablets of $400 \pm 10 \mathrm{mg}$ were prepared from the granules by compressing them in an Erweka automated tableting machine (Model EP-1, Heusenstamn, Germany). Before compression, the depth of the die and punches were adjusted to produce the desired strength of the tablet. After this was achieved, the machine was then allowed to produce the tablets automatically for $30 \mathrm{~min}$. After ejection, the tablets were stored over silica gel for $24 \mathrm{~h}$ to allow for elastic recovery and hardening.

\section{Coating of tablets}

Tablet coating was performed in a high efficiency coating machine (BG-80, Zhejiang, China) with 2 spray guns. Tablet cores were pre-heated to about $40^{\circ} \mathrm{C}$ in the coating pan. The spray gun was filled with $3 \% \mathrm{w} / \mathrm{v}$ Cissus coating dispersion and operated at a proper flow rate. The pan was set into motion and coating solution was sprayed onto the falling cores under a suitable air pressure (30-35 psi). Upon completion of the seal coating, the air heater was switched off and the tablets were blown-dried for 20-25 min in the coating pan.

\section{Uniformity of weight for tablets}

Ten tablets were weighed individually and collectively using a Mettler electronic balance (Model FA2104A, United States) and the average weight was determined. The percentage deviation was then calculated from the average weight.

\section{Tablet hardness and friability}

The load $(\mathrm{N})$ required to diametrically break the tablet was determined at room temperature using a DBK tablet hardness tester (Model EH01, Mumbai, India). The average readings for 10 tablets were taken as the crushing strength. The percentage friability of the tablets was determined with ten tablets using a DBK Friability test apparatus (Model 40FTA01, England) operated at $25 \mathrm{rpm}$ for $4 \mathrm{~min}$.

\section{Disintegration and dissolution test}

The disintegration time of the tablets was determined in distilled water at $37 \pm 0.5^{\circ} \mathrm{C}$ using a DBK Disintegration rate test apparatus (40TDA01, Mumbai, India). The dissolution time of the tablet was determined using the DBK dissolution rate test apparatus (40DRV01, Mumbai, India) containing $900 \mathrm{~mL}$ of phosphate buffer $\mathrm{pH} 6.8$ maintained at $37 \pm 1^{\circ} \mathrm{C}$ at a paddle speed of $50 \mathrm{rpm}$. Samples $(5 \mathrm{~mL})$ of the dissolution medium were withdrawn at different time intervals and replaced with fresh $(5 \mathrm{~mL})$ dissolution medium at the same temperature. The samples were spectrophotometrically analyzed at a wavelength of $224 \mathrm{~nm}$ using a UV spectrophotometer (LAMBDA 12, Perkin Elmer $\mathrm{GmbH}$, Urberlingen, Germany). The percentage drug released was plotted against time.

\section{Data presentation and analysis}

Most of the experiments were performed in triplicate, for film thickness, 10 readings per sample had to be taken at different points on the film surface while the number of tablets used for evaluating tablet properties vary depending on the type of test and specifications in official compendia. In addition, data has been presented as mean \pm standard deviation and " $n$ " indicated on each table. Statistical analysis was carried out using the analysis of variance (ANOVA). The difference between formulations was compared using Turkey Kramer's multiple comparison tests. At 95\% confidence interval, probability values less than or equal to 0.05 were considered significant. 


\section{Results and Discussion}

\section{Properties of gums}

Irvingia and Cissus gums are natural polymers obtained from local edible sources in Nigeria and work is ongoing to fully characterize and determine their chemical structures. HPMC is a standard polymer which has been chemically characterized and is generally used as excipient in food and pharmaceutical industry. Moreover, pursuant to 21 CFR 5170-30, the use of HPMC food or pharmaceuticals is generally recognized as safe (GRAS). ${ }^{15}$ The functional and proximate properties of the polymers are presented in Table 1 . The results showed that the WAC, swelling index, crude fiber and protein for Irvingia gum were significantly higher $(\mathrm{p}<0.05)$ than that of Cissus. On the other hand, Cissus gum exhibited higher values of solubility, carbohydrate and ash. HPMC demonstrated higher solubility, the swelling and WAC could not be determined due to the free solubility in water and other proximate compositions were lower compared to the test polymers showing higher levels of purity. Water absorption capacity and swelling index are important functional parameters of polymers. The interaction between the gums with water showed that these polymers are hydrogels due to their ability to absorb and hold more than 50 times their weight of water as observed from the swelling index.

The formation of a stable gel by the polymers in aqueous media indicates the presence of tangles, cross-linkages or crystal-like regions within the polymer network. ${ }^{15,16}$ The suitability of gums as food or pharmaceutical excipients can be predicted by the dynamics of response when water moves in and out of hydrogels. The swollen state of hydrogels is a consequence of the balance between cohesive and hydration forces on the network of the polymer chains. Hydrophilic polymers, such as these gums, generally swell when water molecules interact with the polar groups mainly hydroxyl and carboxyl on the polymer backbone or side chains. ${ }^{16}$

The protein content of the polymers are ranked Irvingia $<$ Cissus $<$ HPMC and this could be attributed to their different botanical source. Similar hydrocolloids such as gelatin, Arabic gum, and mesquite are generally rich in protein and thus act as stabilizers. This is because they have sufficient hydrophobic groups which serve as bonding points as well as hydrophilic groups that reduce surface tension in a liquid-liquid or liquid-gas interface. ${ }^{17,18}$ The high content of carbohydrate found in the polymers respectively indicates the presence of sugar molecules.

Irvingia, Cissus and HPMC showed relatively low ash values in the order of HPMC < Irvingia < Cissus. Adulteration by sand or earth can be detected using the ash content which normally consists of inorganic mixtures of
Table 1. Functional and proximate properties of Irvingia and Cissus gum

\begin{tabular}{|l|c|c|c|}
\multicolumn{1}{|c|}{ Parameter } & Irvingia & Cissus & HPMC \\
\hline Solubility (\%) & $8.73 \pm 0.04$ & $15.73 \pm 0.18$ & $99.75 \pm 0.03$ \\
WAC (\%) & $73.00 \pm 2.11$ & $50.60 \pm 1.39$ & ND \\
Swelling capacity (\%) & $60.00 \pm 2.34$ & $53.00 \pm 2.54$ & ND \\
Moisture content & $9.55 \pm 1.03$ & $8.56 \pm 2.09$ & $4.87 \pm 0.19$ \\
Crude fibre (\%) & $29.75 \pm 3.11$ & $9.80 \pm 2.10$ & $8.04 \pm 2.17$ \\
Protein (\%) & $5.00 \pm 0.98$ & $3.00 \pm 0.34$ & $0.02 \pm 0.00$ \\
Carbohydrate (\%) & $44.70 \pm 1.21$ & $74.25 \pm 1.27$ & $76.89 \pm 6.81$ \\
Ash (\%) & $2.00 \pm 0.02$ & $3.00 \pm 0.07$ & $1.78 \pm 0.01$ \\
\hline
\end{tabular}

$\mathrm{ND}=$ not determinable because of free solubility.

carbonates, phosphates, silicates and silica. Low ash values suggest the presence of higher organic than inorganic constituents, which exhibit high purity of the materials. The ash content of Irvingia was quite similar to that reported for Chrysophylum albidum gum (2.0\%) in a recent study $^{18}$ while in Cissus it was higher. In addition, the ash content of Irvingia and Cissus was lower than that earlier reported for Xanthan gum. ${ }^{19}$ This implies, therefore, that the Irvingia gabonensis and Cissus pulpunea used in this study acquired low levels of contamination during gathering, extraction, processing and storage.

The results of elemental assessments for Irvingia and Cissus gums are presented in Table 2. They reveal the presence of calcium, magnesium, potassium, sodium, manganese, iron, copper and zinc, which are not harmful to the body, while heavy metals like cobalt, lead and cadmium, which may present toxicity, were absent. HPMC is not included, because official compendium has profiled it as GRAS.

Scanning electron micrographs (SEM) of the gums is presented in Fig. 1. Irvingia and Cissus gums showed characteristic irregularly-shaped particles with rough surfaces. Particle shape is one of the physical properties influencing powder packing and flow especially in tableting procedures. ${ }^{20}$

Table 2. Elemental composition of Irvingia and Cissus gum

\begin{tabular}{|l|c|c|}
\multicolumn{1}{c|}{ Parameter } & Irvingia & Cissus \\
\hline Calcium & 0.53 & 1.43 \\
Magnessium & 0.45 & 0.41 \\
Potassium & 0.94 & 1.14 \\
Sodium & 10.30 & 10.20 \\
Manganese & 1.56 & 0.51 \\
Iron & 0.38 & 0.77 \\
Copper & 0.33 & 0.53 \\
Zinc & 1.40 & 1.20 \\
Cobalt & 0.00 & 0.00 \\
Lead & 0.00 & 0.00 \\
Nickel & 0.21 & 0.36 \\
Chromium & 0.21 & 0.39 \\
Cadmium & 0.00 & 0.00 \\
\hline
\end{tabular}




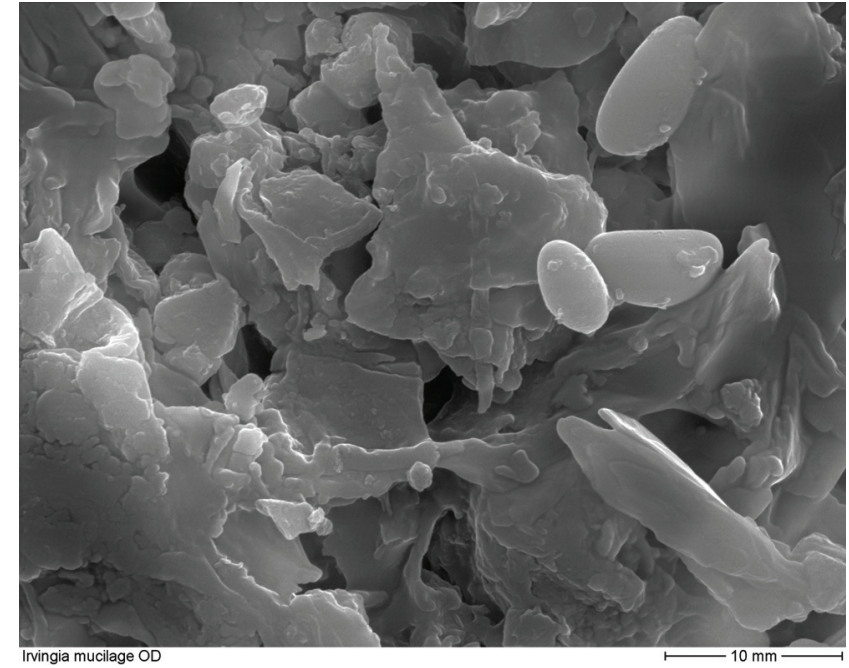

Fig. 1a. Scanning electron micrographs of Irvingia gum

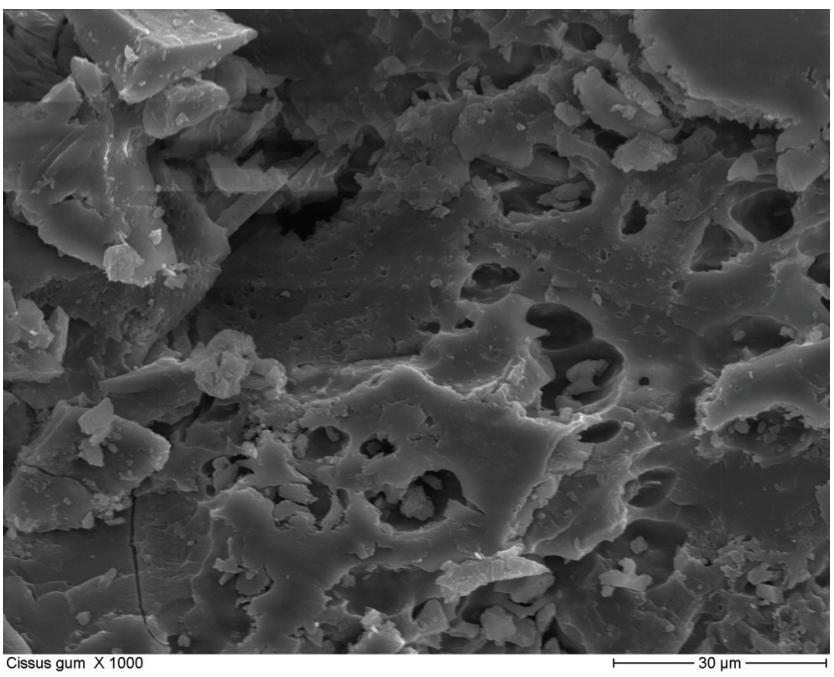

Fig. 1b. Scanning electron micrographs of Cissus gum (magnification $\times 1000$ )

The viscosity profiles of the natural gums are presented in Fig. 2. Irvingia, Cissus and HPMC showed an increase in viscosity as concentration increases. This may be attributed to intermolecular friction exerted when layers of fluids attempt to slide over one another indicating that there is an increase in the internal resistance of the gum to flow as more molecules are available in the higher concentrations. Cissus gum generally showed a higher viscosity profile than Irvingia, probably due to structural differences or the presence of more hydrophilic groups. However, both gums showed high viscosity values compared to HPMC. The HPMC grade used in this study is E5 Premium LV; hence, the low viscosity. The addition of humectant increased the viscosity of all the polymers, though this effect was more pronounced with Cissus gum. Thus, the humectant appeared to modify the viscosity of the polymers to varying degrees.

The result of the moisture sorption of Irvingia and Cissus gums and HPMC at varying levels of relative humidity is given in Fig. 3. The moisture sorption profiles showed that the gums were moderately hygroscopic, as their moisture uptake was greater than $5 \%$ after storage below
$60 \%$ RH, and less than 40 at 90\% RH. There were also no significant differences $(\mathrm{p}<0.05)$ in the moisture sorption of the 2 gums. HPMC showed slightly hygroscopic characteristics as the moisture uptake between 75 and $90 \% \mathrm{RH}$ was less than $15 \%$. In addition, the moisture sorption of Cissus and Irvingia gum was relatively high compared to HPMC, which showed the least sorption of moisture at relative humidity. Abramovic and Klofutar ${ }^{21}$ reported the case of low acyl gellan gum, which was found to absorb more water at high relative humidity, while at low relative humidity, it absorbed much less amounts of water.

\section{Properties of films}

Homogeneity and appearance of the films were examined by visual observation. The dried films of Irvingia and Cissus were opaque and flexible when handled and were easily removed from the cast plate. Films obtained using HPMC were transparent, glassy in appearance, flexible and easy to remove from the plates. Generally, films containing no humectant dried much faster than those containing humectant. Humectant has been reported as interfering with polymeric chain association, thus decreasing the rigidity of the network and producing a less ordered film structure. ${ }^{22}$

The swelling properties of Irvingia and Cissus films are presented in Table 3. The results showed that the swelling index of the films reduced with the increase in concentration for both gums, though without a significant differ-

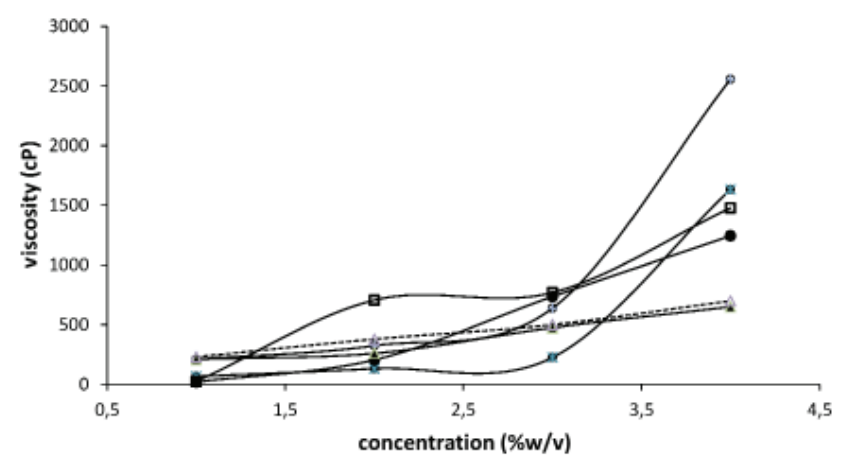

Fig. 2. Viscosity profiles of polymer dispersions $(-$ - Cissus, O - Cissus + humectant, - Irvingia, $\square$ - Irvingia + humectant, $\mathbf{\Delta}$ - HPMC, $\triangle$ - HPMC + humectant)

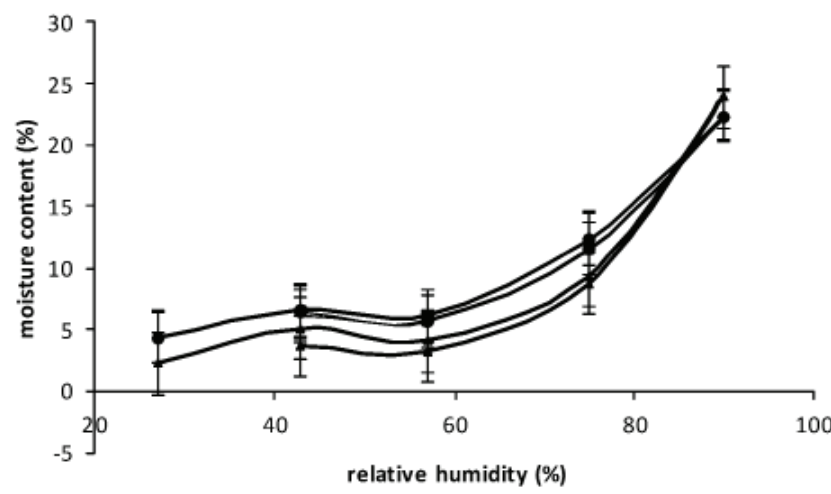

Fig. 3. Moisture sorption curve for gums of Irvingia $(\bullet)$, Cissus ( $\mathbf{\square})$ and HPMC 
Table 3. Swelling index of dried films at different $\mathrm{pH}($ mean $\pm \mathrm{SD}, \mathrm{n}=3$ )

\begin{tabular}{|l|c|c|c|c|}
\multirow{4}{*}{ Gum } & $\begin{array}{c}\text { Concentratin } \\
(\% w / v)\end{array}$ & 4.75 & 6.0 & 7.4 \\
\cline { 3 - 5 } Irvingia & 2.0 & $5.87 \pm 0.68$ & $6.08 \pm 0.75$ & $6.52 \pm 1.84$ \\
& 3.0 & $5.63 \pm 1.66$ & $5.66 \pm 0.55$ & $6.18 \pm 0.70$ \\
& 4.0 & $5.44 \pm 0.79$ & $5.59 \pm 0.18$ & $6.01 \pm 0.88$ \\
\multirow{3}{*}{ Cissus } & 2.0 & $10.08 \pm 0.97$ & $12.73 \pm 1.90$ & $10.76 \pm 0.44$ \\
& 3.0 & $6.97 \pm 0.27$ & $12.72 \pm 1.00$ & $10.55 \pm 0.31$ \\
& 4.0 & $6.49 \pm 0.29$ & $11.98 \pm 1.09$ & $10.32 \pm 0.78$ \\
HPMC & 2.0 & $\mathrm{ND}$ & $\mathrm{ND}$ & $\mathrm{ND}$ \\
& 3.0 & $\mathrm{ND}$ & $\mathrm{ND}$ & $\mathrm{ND}$ \\
& 4.0 & $\mathrm{ND}$ & $\mathrm{ND}$ & $\mathrm{ND}$ \\
\hline
\end{tabular}

$\mathrm{ND}=$ not determinable because of free solubility.

ence. In addition, swelling increased with the increase in the $\mathrm{pH}$ of the medium for irvingia, while it is reduced for cissus. HPMC films absorbed the phosphate buffer rapidly within twenty minutes, causing a breakdown and erosion of the film. The reason for this may be the free solubility of HPMC causing the degradation of the polymer backbone, thus leading to film disintegration. Hence, HPMC dried film did not show any swelling compared to Cissus and Irvingia films. The swelling capacity provides evidence of the magnitude of interaction between polymer chains within the amorphous and crystalline domains. ${ }^{23}$

The results of the thickness of Irvingia and Cissus dried films are presented in Table 4. The thickness of films increased with the increase in the concentration of the gums, and films containing humectant were thicker, though without a significant difference $(\mathrm{p}>0.05)$ for Cissus. The thickness of Irvingia films containing humectant

Table 4. Elemental composition of Irvingia and Cissus gum

\begin{tabular}{|c|c|c|}
\hline Polymer & $\begin{array}{c}\text { Concentration } \\
(\% \mathrm{w} / \mathrm{w})\end{array}$ & $\begin{array}{l}\text { Thickness } \\
(\mathrm{mm})\end{array}$ \\
\hline \multirow{3}{*}{ Cissus } & 2 & $0.110 \pm 0.006$ \\
\hline & 3 & $0.120 \pm 0.005$ \\
\hline & 4 & $0.130 \pm 0.008$ \\
\hline \multirow{3}{*}{ Cissus + humectant } & 2 & $0.120 \pm 0.003$ \\
\hline & 3 & $0.120 \pm 0.005$ \\
\hline & 4 & $0.130 \pm 0.007$ \\
\hline \multirow{3}{*}{ Irvingia } & 2 & $0.110 \pm 0.001$ \\
\hline & 3 & $0.140 \pm 0.015$ \\
\hline & 4 & $0.170 \pm 0.021$ \\
\hline \multirow{3}{*}{ Irvingia + humectant } & 2 & $0.120 \pm 0.002$ \\
\hline & 3 & $0.220 \pm 0.012$ \\
\hline & 4 & $0.240 \pm 0.014$ \\
\hline \multirow{3}{*}{ HPMC } & 2 & $0.065 \pm 0.031$ \\
\hline & 3 & $0.069 \pm 0.017$ \\
\hline & 4 & $0.096 \pm 0.037$ \\
\hline \multirow{3}{*}{ HPMC + humectant } & 2 & $0.074 \pm 0.032$ \\
\hline & 3 & $0.102 \pm 0.029$ \\
\hline & 4 & $0.107 \pm 0.017$ \\
\hline
\end{tabular}

were, however, significantly higher $(\mathrm{p}<0.05)$ than for those without. The humectant might have increased the thickness due to its capacity to increase the viscosity of the gums as shown in the viscosity profiles in Fig. 2.

Moisture sorption has been reported to be one of the most sensitive techniques for assessing the variation in the amorphous or crystalline content of polymers ${ }^{24}$ as well as predicting some physicochemical and functional properties. ${ }^{25}$ This is because the moisture uptake is predominantly due to the interaction of the water molecules with the amorphous part of the polymer network. The moisture sorption profiles of Cissus and Irvingia gums were quite similar as shown in Fig. 3. This could indicate a similarity in their polymer chain arrangement showing comparable amorphous domains. ${ }^{10}$ Figures 4 and 5 showed the moisture sorption profiles of films with and without humectant respectively. Generally, the moisture sorption increases with increase in relative humidity with the highest occurring at $90 \% \mathrm{RH}$ for all films. At lower RH (43 and 57\%), Cissus gum had significantly higher $(\mathrm{p}<0.05)$ values than HPMC and Irvingia but at a higher RH (75 and 90\%), Irvingia films showed higher moisture sorption. Cissus films containing humectant seems to adsorb a significantly higher $(\mathrm{p}<0.05)$ amount of water than Irvingia and HPMC. This revealed that the effect of humectant modified the moisture sorption process in the films. Humectants are agents that help to conserve water in formulations, so as to avoid drying up.

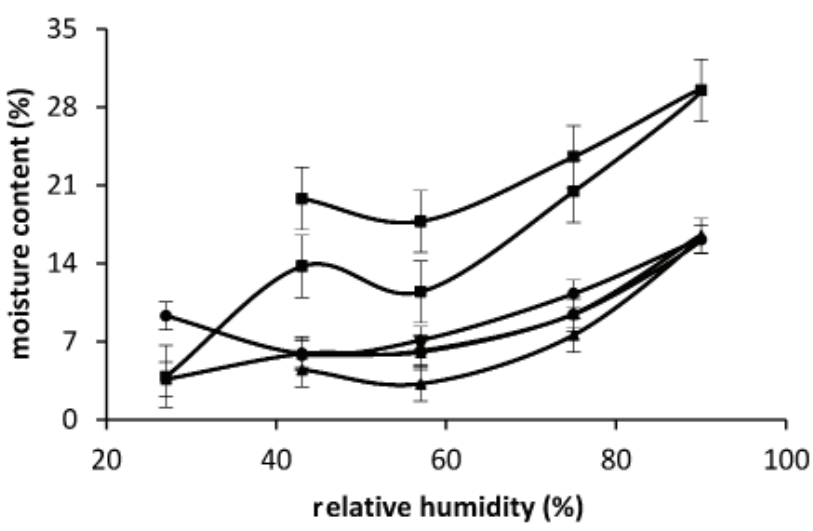

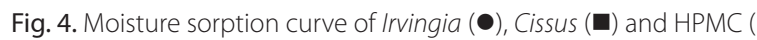
films containing humectant

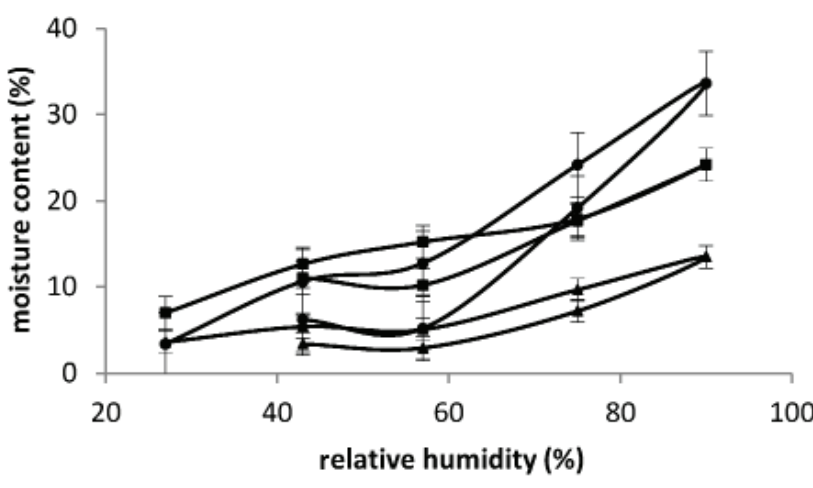

Fig. 5. Moisture sorption curve of Irvingia (•), Cissus ( $\mathbf{\square})$ and HPMC films prepared without humectant 


\section{Tablet properties of uncoated and coated ibuprofen tablets}

The mechanical and release properties of ibuprofen coated and uncoated tablets are presented in Table 5 . The crushing strength (CS) for uncoated tablets was lower than that obtained for Cissus-coated and HPMC-coated tablets. This could be because of the decrease in porosity and subsequent formation of stronger bonds at closer inter-particulate contact due to the concentration of the polymer gum. ${ }^{26}$ The result also showed that the differences in the CS values of the uncoated and coated were significant $(\mathrm{p}<0.05)$. Friability $(\mathrm{F})$ test is a measure of the ability of tablets to withstand abrasion during shipping and handling. Conventional compressed tablets that lose less than $1 \%$ of their weight during the friability test are generally considered acceptable. Friability was significantly $(\mathrm{p}<0.05)$ lower for Cissus-coated and HPMC-coated tablets than uncoated ones. This decrease may be attributed to the greater amount of particle-particle contact points which created more solid bonds, resulting in tablets with more resistance to fracture and abrasion, thus presenting higher crushing strength and lower friability. Generally, the mechanical properties of coated tablets as summarized by CS/Fr were significantly higher $(\mathrm{p}<0.05)$ than that of uncoated showing improved properties.

The disintegration time (DT) of uncoated and Cissus-coated ibuprofen tablet is presented in Table 5. It was observed that the disintegration time of coated tablets was significantly higher $(\mathrm{p}<0.05)$ than it was in the case of uncoated tablets. This could be a result of a decrease in tablet porosity or a reduction in the capillary microstructure of the polymer coat on the tablets. ${ }^{27}$ Particle rearrangement, fragmentation and deformation may result in the closure of the intra and inter-granular pore spaces, thereby reducing the capillary microstructure of the tablets. ${ }^{27}$ Consequently, water penetration into tablets would be retarded, leading to an increase in the disintegration. Tablet disintegration time for uncoated ibuprofen tablets was generally lower, probably due to the lack of particle re-arrangement, resulting in faster water penetration to facilitate disintegration. In addition, HPMC-coated tab-

Table 5. Tablet properties of uncoated and Cissus-coated Ibuprofen tablets

\begin{tabular}{|l|c|c|c|}
\multicolumn{1}{|c}{ Parameters } & $\begin{array}{c}\text { Uncoated } \\
\text { Ibuprofen } \\
\text { tablets }\end{array}$ & $\begin{array}{c}3 \% \mathrm{w} / \mathrm{v} \\
\text { Cissus-coated } \\
\text { Ibuprofen } \\
\text { tablet }\end{array}$ & $\begin{array}{c}3 \% \mathrm{w} / \mathrm{v} \\
\text { HPMC-coated } \\
\text { lbuprofen } \\
\text { tablet }\end{array}$ \\
\hline Thickness (mm) & $6.012 \pm 0.010$ & $6.030 \pm 0.010$ & $7.072 \pm 0.073$ \\
Crushing strength (N) & $53.220 \pm 2.240$ & $77.530 \pm 3.910$ & $76.673 \pm 3.871$ \\
Friability & $0.760 \pm 0.010$ & $0.200 \pm 0.040$ & $0.291 \pm 0.043$ \\
CS/Fr & 70.026 & 387.650 & 263.481 \\
$\begin{array}{l}\text { Disintegration time } \\
\text { (min) }\end{array}$ & $15.930 \pm 0.940$ & $68.930 \pm 0.530$ & $56.670 \pm 3.192$ \\
$\mathrm{t}_{50}$ & 12.032 & 19.103 & 32.592 \\
$\mathrm{t}_{80}$ & 26.035 & 36.105 & 48.543 \\
\hline
\end{tabular}

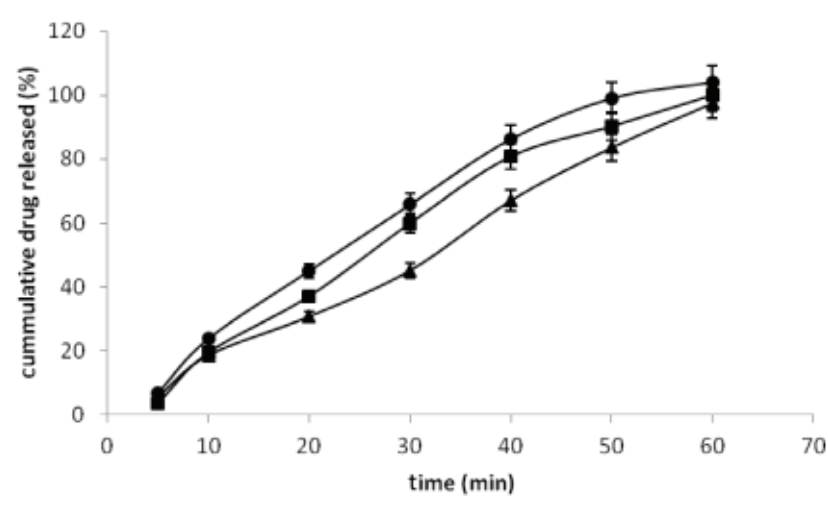

Fig. 6. Dissolution profiles for uncoated (•), Cissus-coated $(\mathbf{\square})$ and HPMC-coated ( $\mathbf{\Delta})$ Ibuprofen tablet

lets yielded a lower DT compared to Cissus-coated tablets. The BP stipulates 1-h for film-coated tablets while uncoated have $15 \mathrm{~min}$. The HPMC-coated tablets disintegrated within $1 \mathrm{~h}$ showing a higher performance over the Cissus-coated tablets.

The dissolution profiles of ibuprofen drug from Cissus-coated, HPMC-coated tablets and uncoated tablets are shown in Fig. 6 and the values of $t_{50}$ and $t_{80}$ (time required for 50 and $80 \%$ of ibuprofen to be released respectively) are included. The dissolution profiles showed that $80 \%$ of the drug was released in $36 \mathrm{~min}$ and $50 \%$ of the drug released at 19 min for Cissus-coated tablets, while uncoated ibuprofen tablet, gave $80 \%$ of drug release at $26 \mathrm{~min}$ and $50 \%$ of drug release at $12 \mathrm{~min}$. HPMC-coated tablets yielded 32.59 and 48.5 for 50 and $80 \%$ drug release Thus, tablet coated using Cissus gum and HPMC had higher dissolution times than uncoated tablets, showing that the coating can be used to control the release of ibuprofen.

\section{Conclusion}

The proximate, functional and elemental properties of Irvingia and Cissus gums in this study have demonstrated their potential as polymers for pharmaceutical use. The mechanical properties of Cissus-coated tablets improved, while there was a delay in drug release, revealing that the film provided effective coating.

\section{References}

1. Kulkarni AP, Shaikh YR, Dehghan GR. Application of neem gum for aqueous film coating of ciprofloxacin tablets. Int J Appl Res Nat Prod. 2013;16(3):1-5.

2. Ogaji IJ, Nep El, Audu-Peter JD. Advances in natural polymers as pharmaceutical excipients. Pharm Anal Acta. 2012;3:146-151.

3. Ibrahim H, Rai PP, Bangudu AB. Pharmacognostic studies of the Stem Bark of Cissus polpunea Guill \& Perr. Glimp Plant Res. 1993;1:175-180.

4. Iwe MO, Attah MA. Functional properties of the active ingredients of Cissus Pulpunea Guill. Perr. Books Ltd. Ibadan Nig. $2^{\text {nd }}$ ed. 1993;289-292.

5. Joseph JK. Physico-chemical attributes of Wild Mango (Irvingia gabonensis) Seeds. Bioresource Technology. 1995;53:179-181. 
6. Ladipo DO, Fondoun JM, Ganga N. Domestication of the Bush Mango (Irvingia Spp). Some exploitable intraspecific variations in west and central Africa. In: Domestication and International Conference Held In Nairobi, Kenya. Non-Wood Forest Products. Food and Agriculture Organisation (E.A.O). Rome, Italy 1996;9:193-205.

7. Agbor LON. Marketing trends and potentials for Irvingia gabonensis products in Nigeria. Proc. ICRAF-IITA Conf. Irvingia gabonensis, May 3-5, Ibadan, Nigeria, 1994.

8. Odeku OA, Patani B. Evaluation of dika nut mucilage (Irvingia gabonensis) as a binding agent in metronidazole tablet formulation. Pharm Dev Technol. 2005;10:439-446.

9. Isimi CY, Kunle OO, Bangudu AB. Some emulsifying and suspending properties of the mucilage extracted from kernels of Irvingia gabonensis. Boll Chim Farm. 2000;139:199-204.

10. Odeku OA, Lamprecht A, Okunlola A. Characterization and evaluation of four natural gums as polymers in formulations of diclofenac sodium microbeads. Int J Biol Macromol. 2013;58:113-120.

11. Odeku OA, Itiola OA. Evaluation of the effect of Khaya gum on the mechanical and release properties of paracetamol tablets. Drug Dev Ind Pharm. 2003;29(3):311-320.

12. Association of Official Analytical Chemists (A.O.A.C) Official Methods of Analysis, Centennial Ed. 14, Washington D.C USA. 1984, ISBN 13: 9780935584240.

13. Kaur M, Oberoi DPS, Sogi DS, Gill BS. Physicochemical, morphological and pasting properties of acid treated starches from different botanical sources. J Food Sci Technol. 2011;48(4):460-465.

14. Lin YC, Chen X. Moisture sorption-desorption-resorption characteristics and behaviour of the epoxy system. Polym. 2005;46:1199412003.

15. Kosmulski M, Gustafsson MJ, Rosenholm JB. Ion specificity and viscosity of rutile dispersions. Col Polym Sci. 1999;277(6):550-556.

16. Galindo-Rodríguez SA, Puel F, Briançon S, Allémann E, Doelker E, Fessi $\mathrm{H}$. Comparative scale-up of three methods for producing ibuprofen-loaded nanoparticles. Eur J Pharm Sci. 2005;25:357-367.

17. Lopez VO, Garcia MA, Zaritzky EN. Film forming capacity of chemically modified corn starches. Carb Polym. 2007;73:573-581.

18. Ajala TO, AkinAjani OD, Ihuoma-Chidi C, Odeku OA. Chrysophyllum albidum mucilage as a binding agent in paracetamol tablet formulations. J Pharm Inves. 2016; 46(6):565-573.

19. Sciarini LS, Maldonado F, Ribotta PD, Pérez GT, León AE. Chemical composition and functional properties of Gleditsia triacanthos gum. Food Hydrocol. 2009;23:306-313.

20. Okafor IS, Chukwu A, Udeala OK. Some physical properties of Grewia gum. Nig J Polym Sci Tech. 2001;2(1):76-83.

21. Abramovic $\mathrm{H}$, Klofutar $\mathrm{C}$. Water adsorption isotherms of some gellan gum samples. J Food Eng. 2006;77(3):514-520.

22. Sothornvit R, Krochta JM. Plasticizers in edible films and coatings, in Innovations. In: J. H. Han (Ed.), Innovations in food packagings Amsterdam, The Netherlands: Elsevier. 2005:403-428.

23. Hover R. Composition, molecular structure and physicochemical properties of tuber and root starches: a review. Carbo Polym. 2001;4:29-35.

24. Manek RV, et al. Physical, thermal and sorption profile of starch obtained from Tacca leontopetaloides. Starch-Starke 2005;57(2):55-61.

25. Bravo-Osuna I, Ferrero C, Jiménez-Castellanos MR. Water sorptiondesorption behaviour of methyl methacrylate-starch copolymers: Effect of hydrophobic graft and drying method. Eur J Pharm Biopharm. 2005;59:537-548.

26. Beery KE, Ladisch MR. Chemistry and properties of starch-based dessicants. Enzym Microbial Tech. 2001;28:573-581.

27. Luangtanan-Anan M, Fell JT. Bonding mechanisms in tableting. Inter J Pharm. 1990;60:197-202. 
